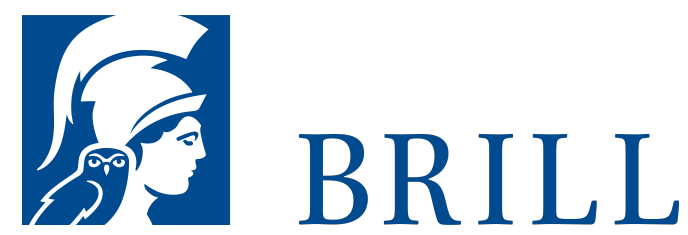

\title{
Das Haremsfenster
}

Zur fotografischen Eroberung Ägyptens im 19. Jahrhundert

Author: Felix Thürlemann

Die Entdeckung Ägyptens als touristisches Ziel war begleitet von einer reichen Produktion fotografischer Bilder. Diese hatten mit der Lebenswirklichkeit der Bewohner Ägyptens kaum mehr etwas zu tun, umso mehr aber mit den Phantasien und Phantasmen der westlichen Touristen.

Die Aufnahmen stammten alle aus den Ateliers auswärtiger Fotografen und zeigten nach dem Prinzip des Orientalismus das, wodurch sich die traditionelle muslimische Kultur von der westlichen unterschied. Ein besonders beliebtes Motiv waren die Haremsfenster oder Mashrabiyas, die das Erscheinungsbild der traditionellen Stadtviertel Kairos prägten. Die an den privaten Wohnräumen angebrachten Erker erlaubten es den Frauen, das Treiben im Hof und auf der Straße zu beobachten, ohne dabei selbst gesehen zu werden. Für die Fotografen wurde der architektonische Schleier zu einem emblematischen Zeichen, das den Orient als solchen charakterisierte. 
Biographical Note

Felix Thürlemann, geboren 1946 in St. Gallen, war bis 2014

Professor für Kunstwissenschaft und Kunstgeschichte an der Universität Konstanz.

For more information see brill.com

Order information: Order online at brill.com +44 330 333 0049 | customerservices@brill.com Submission information: brill.com/authors

Titles published by Brill | Fink, Brill | mentis or Brill | Schöningh: +49(o)71 5413279216 | brill@brocom.de 